\title{
ПИТАННЯ ФОРМУВАННЯ МОТИВАЦІЇ ДО НАВЧАННЯ ТА ОСНОВ КЛІНІЧНОГО МИСЛЕННЯ У АНГЛОМОВНИХ СТУДЕНТІВ МЕДИЧНОГО УНІВЕРСИТЕТУ
}

\author{
М. М. Лебедюк, І. В. Ашаніна \\ Одеський національний медичний університет
}

\section{QUESTIONS OF FORMING MOTIVATION TO STUDYING AND BASES OF MEDICAL THINKING IN THE FOREIGN STUDENTS OF MEDICAL UNIVERSITY}

\author{
M. M. Lebediuk, I. V.Ashanina \\ Odesa National Medical University
}

\begin{abstract}
У статті представлений погляд на питання формування мотивації до навчання та необхідність створення лікарського мислення - як кінцеве завдання вивчення клінічної дисципліни.

This article adduces point of view to questions of the forming of motivation for learning and essential for the clinical thinking - as top of the studying for clinical subject.
\end{abstract}

Вступ. На сучасному етапі в умовах існування високих технологій та жорсткої конкуренції пріоритетним $є$ надавання професійних медичних послуг, що стає можливим за умов якісної медичної освіти, яка передбачає в першу чергу формування у студентів майбутніх лікарів лікарського мислення, вміння розмовляти 3 пацієнтом, визначати всі види діагнозів, проводити диференційний діагноз, трактувати дані лабораторних та інструментальних досліджень, призначати адекватне лікування і навчальний процес повинен забезпечити виконання цих завдань.

Основна частина. Посилення інтересу до навчання повинно включати такі параметри щодо заохочення і формування мотивації до навчання: по-перше, викладач повинен бути особистістю, всебічно розвинутою, по-друге, знання іноземної мови повинно бути на достатньо високому рівні, вміти формувати не тільки багаж професійно важливих знань та умінь, але й науково-культурний кругозір, розвиток духовних потреб, комунікативних, мовних (за Н. Л. Коломінським).

Особливо важливе формування мовних здібностей. Було відмічено, що висловлювання студентів з приводу причин захворювання, вміння вибудовувати логічний ланцюг, $з$ якого виходить майбутній діагноз, диференційний діагноз та ін., залишають бажати кращого. Мабуть, надмірне застосування тестів, зменшення частки “живого” спілкування, збільшення частки самостійної роботи студента - це є тому причина.

Ми аналізували навчання студентів на кафедрі дерматологіїта венерології, дисципліни, яка, як і всі клінічні дисципліни, ставить перед майбутніми лікарями практичні завдання діагностики та лікування. Важливим фактором $\epsilon$ розуміння студентами, що дисципліна $\epsilon$ глибоко інтегрованою в інші медичні науки, без знання таких предметів, як гістологія, патоморфологія, фізіологія та ін., не можливе розуміння процесів, які йдуть у шкірі, без розуміння внутрішньої медицини, зокрема ендокринології, інфекційних хвороб та ін., не можливе проведення диференційної діагностики, без знання фармакології, зокрема клінічної фармакології-неможливо призначити адекватне лікування. Складається враження, що деякі студенти сприймають кожний новий предмет як окрему ситуацію і не прагнуть всебічно роздивлятись іiі.

Таким чином, основним завданням $€$ формування лікарського, клінічного мислення, яке базується на багаторічному досвіді української дерматовенерологічної школи, яка, як відомо, вийшла з європейської науки і бере свій початок з 1869 р. (становлення київської дерматовенерологічної школи), з 1904 р. кафедра дерматовенерології створена в м. Одесі. Основним постулатом старої клінічноїшколи було: "Роби, як я, засвоюй все, що було до тебе, та йди далі”.

(c) М. М. Лебедюк, I. В. Ашаніна 
Безумовно, необхідно гармонійно поєднувати теорію та практику. Останнім часом достатньо успішно використовують тестові завдання. Ситуаційні, клінічні задачі, які багато ілюстровані на нашій кафедрі, крім цього використовуються навчальні фільми, але незамінним залишається спілкування з пацієнтом "коло ліжка хворого”, збір анамнезу, об'єктивне та суб'єктивне дослідження, вміння спілкуватися з хворим, задавати правильні питання, оскільки лікар - це ще й психолог. Тому на курацію виділено достатню кількість годин. Дуже важливо засвоїти і донести до студентів найважливіші етапи клінічного мислення, наприклад, що діагностика - це наукова дисципліна, яка складається з двох основних розділів:

1) вивчення методів спостереження за хворим;

2) вивчення діагностичного значення симптомів хвороб, особливостей клінічного мислення при розпізнаванні захворювання - методика діагнозу.

Діагнози за методами побудови бувають:

1) прямий;

2) диференційний;

3) синтетичний (повний);

4) шляхом спостереження;

5) за лікувальним ефектом.

За часом виявлення:

1) ранній;

2) клінічний;

3) ретроспективний;

4) посмертний.

За ступенем обгрунтування:

1) попередній;

2) кінцевий;

3) під питанням - до верифікації.

Студентів навчають різних діагностичних прийомів і методів, семіотики, фізичних методів обстеження, клінічної інтерпретації результатів лабораторних та

\section{Література}

1. Півторак К. В. Формування особистості та мотивації до навчання у студентів медичного університету / К. В. Півторак, І. В. Феджага // Медична освіта. -2011. - № 4. - C. 28-31.

2. Особливості викладання теоретичних дисциплін студентам факультету підготовки іноземних громадян у вищих навчальних закладах / Т. В. Князевич-Чорна, М. І. Грищук, О. Г. Попадинець, О. В. Бойко // Медична освіта. - інструментальних досліджень, методики проведення диференційного діагнозу. Це процес діагностичного творчого пошуку [3-5].

Також мотивація до навчання формується за рахунок спільної праці викладача та студента, за рахунок опитування на кожному занятті, можливості та прагнення отримати найвищий бал. Додатково на кафедрі працює студентське наукове товариство, $\epsilon$ електронна бібліотека з методичними посібниками, навчальною літературою, тестовими завданнями, в тому числі й англійською мовою.

При виконанні тестових завдань дуже шкодять мобільні телефони, які студенти використовують для пошуку правильної відповіді, особливо англомовні, тому що ресурс Internet заохочує, одна із переваг ресурсу - широке використання англійської мови. У відношенні до англомовних студентів методи навчання майже не відрізняються, питання лише в удосконаленні знань викладачами іноземної мови, та створенні методичних посібників англійською мовою, які відповідають міжнародним стандартам. Серед переваг викладання англійською мовою можна визначити такі:

- англійська мова $є$ міжнародною мовою спілкування;

- англійська мова підвищує “конвертованість освіти”, відкриваючи можливості продовження освіти в інших країнах;

- переважна більшість інформаційних ресурсів англомовні [1,2].

Висновок. Кінцевою метою навчального процесу при вивченні клінічних дисциплін $є$ формування у студентів творчого підходу, лікарського, клінічного мислення, якому передують свідомі мотивації до вивчення навчального матеріалу та інтересу до медицини в цілому.

2011. -№4. - С. 17-19.

3. Билибин А. Ф. О клиническом мышлении / А. Ф. Билибин, Г. И. Царегородцев. - М. : Мед., 1973. - 150 с.

4. Матльований А. Організм і особистість. Діагностика та керування / А. Матльований, В. Белов, А. Котова. - Львів : Вид. Мед. газ. України, 1998. - 147 с.

5. Щербатий А. Й. Медична діагностика / А. Й. Щербатий, В. М. Поліщук. - Рівне, 1996. - 127 с. 